\title{
Infrastructural Challenges in Nigeria and the Effect on the Nigerians Economy: A Review of Literature
}

\author{
Chijindu Okpalaoka
}

Business Management Department, Covenant University, Km 10 Idiroko Road, Ota Ogun State 112212, Nigeria

Corresponding Author Email: chijindu.okpalaokapgs@stu.cu.edu.ng

https://doi.org/10.18280/eesrj.080403

Received: 27 October 2021

Accepted: 22 December 2021

\section{Keywords:}

economic growth, FDI, infrastructural challenges, infrastructure development, Nigerian economy

\begin{abstract}
Infrastructure development is a critical prelude to economic growth and development on a global scale. Most emerging economies with infrastructure deficits have little chance of establishing a sustainable route to national growth, as attracting FDI and advancing essential and noncritical sectors of the economy are near-impossible. Nigeria is trapped in this heinous predicament. Over the years, various administrations have failed to prioritize the building of critical infrastructure. Budgeting has frequently prioritized recurrent expenditures over infrastructure development, leaving the country in a dismal and awful condition of infrastructural presence. This study examines infrastructural challenges in Nigeria and their effect on the Nigerian economy. The research mainly relies on a secondary data source, employs the descriptive approach, and finds that Nigeria's infrastructural state results from state actors' continual negligence. It thus recommends that effective management fosters accountability, lowers corruption, and minimizes waste of resources due to efficiency.
\end{abstract}

\section{INTRODUCTION}

Infrastructure refers to the fundamental physical and organizational elements that enable a society to function, such as roads, bridges, health services, governance, industries, and buildings. It is an industry or the goods, services, and infrastructure that enable an economy to operate [1]. It can be defined broadly as the collection of interrelated internal structures that serve as the basis for a complete development structure. Infrastructure is the mechanism by which an objective or group of objectives is accomplished and the objectives themselves. It is a critical phrase for assessing the development/status of a country, region, or state and individuals. The term is frequently used to refer to the technical structures that underpin society, such as water supply, sewers, roads, national electrical grids, and telecoms.

Also, it is the physical element of interconnected systems that provide commodities and services necessary to aid, sustain, or improve societal living conditions [2]. When viewed technically, infrastructure enables the creation of goods, the distribution of finished goods to the end-users, and essential social services. According to the Online Etymology Dictionary, "infrastructure" means structures that serve as a foundation for any activity or system. In emerging economies, infrastructure refers to roads and other modes of mobility. With the emergence of telecoms in Nigeria, infrastructure took center stage as the products and services required for a business to function. It is classified into two types: and Soft and Hard. Complex infrastructure refers to the extensive physical networks needed for the operation of an advanced industrial nation. At the same time, softness encompasses all organizations required to preserve a country's health, cultural, economic, and economic standards, including that of the educational system, health system, governance system, judiciary system, financial system, and security [3].

\section{LITERATURE REVIEW}

\subsection{Nigerians infrastructure}

Investment in infrastructure is one of the metrics used to evaluate elected leaders' accomplishments and is a necessary component of a strong democracy. In western democracies, enthusiasm for infrastructure development is more significant than in military dictatorships or when compared to developed countries.

This is because infrastructural resources are always in short supply. In democratic governance, developing nations, ethnic agitation, and lobbying are common. This is why the Department of Public Affairs in the U.k. recommended that a dedicated office handle infrastructural project commencement. Nigeria's infrastructural profile, like that of any developing nation, is unremarkable. Housing conditions are deplorable on theoretical and practical levels [4-8]. The majority of facilities are now frail and in desperate need of repairs and renovations. Government is the structure that plans, organizes, governs, and oversees a region's residents, ensuring that everyone has a favorable living environment and a sense of belonging. States have the authority to enact any policies they think necessary to provide a livable climate for all. Infrastructural development in democratic administration is more difficult due to the public's accessibility to government. It entails finding the appropriate project, conducting feasibility and viability studies, and initiating physical development. Numerous problems exist, including those related to funding, technological development, maintenance, and design.

Additionally, the hurdles include ensuring that projects 
match global standards and are constructed responsibly. Greenhouse gas emission standards issued by international bodies such as the International Standard Organization must be met by projects. Air capture and assessment are carried out in villages and towns to ensure that they emit as few greenhouse gases as possible. Also, human settlements must be biodiverse, allowing other animals and plants to coexist; and the natural environment must be conserved for sustainable development, among other things.

Due to a lack of training and motivation, merchants and other technical human resources required for infrastructure development are few. "As a result, a large number of professionals, tradespeople, and senior executives are leaving to other nations [7]. Due to easy money, most teenagers who were supposed to learn a trade have become commercial motorcycle couriers. Many difficulties have not been addressed adequately. Nigeria's chronic lack of fundamental infrastructure necessary to support environmental sustainability and employment - both locally and internationally - and to maintain competitiveness is wellknown for a vast number of local governments, particularly rural ones.

Below are some of the failed infrastructural projects in Nigeria as shown in Figures 1 and 2.

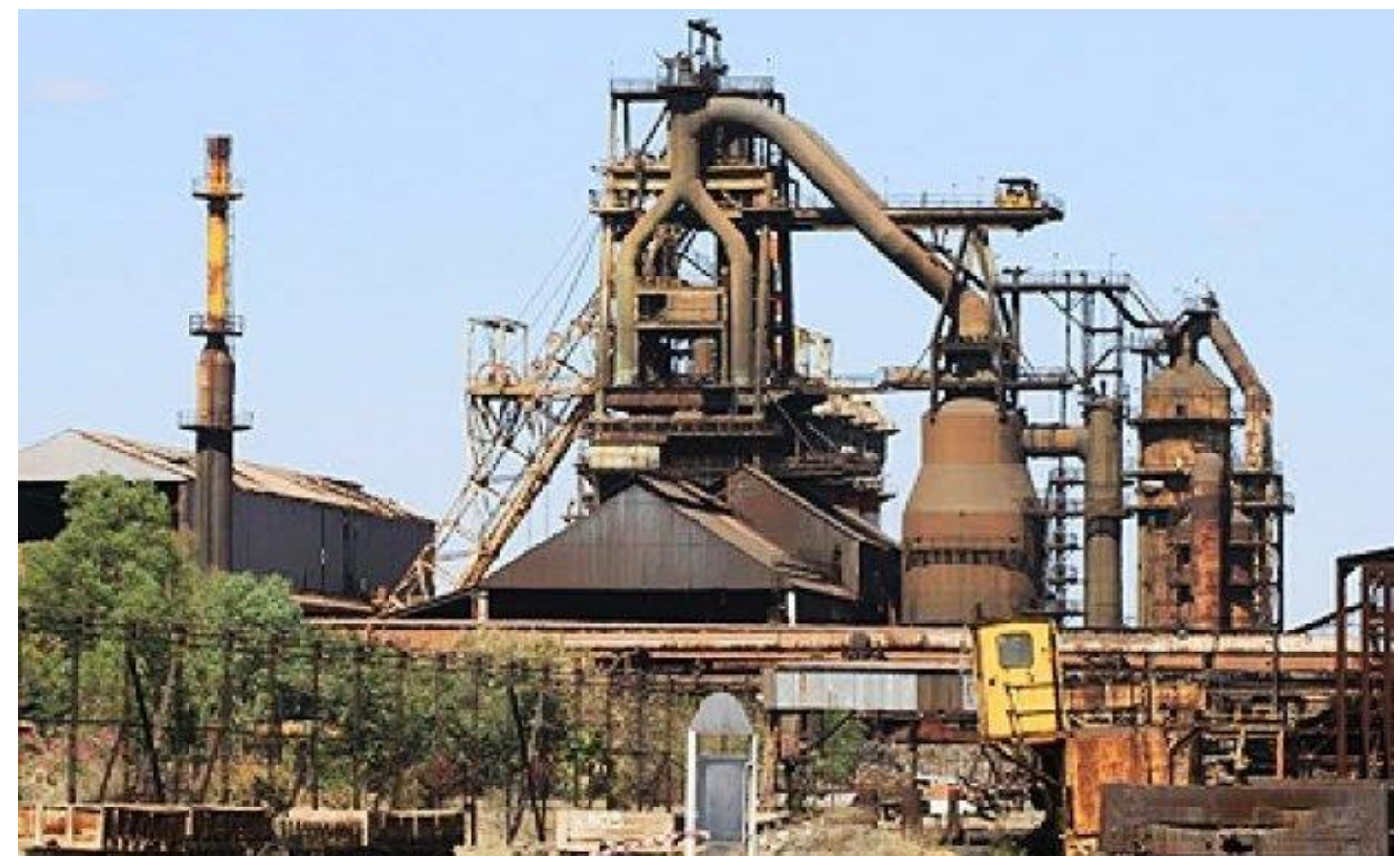

Figure 1. Ajaokuta steel plant

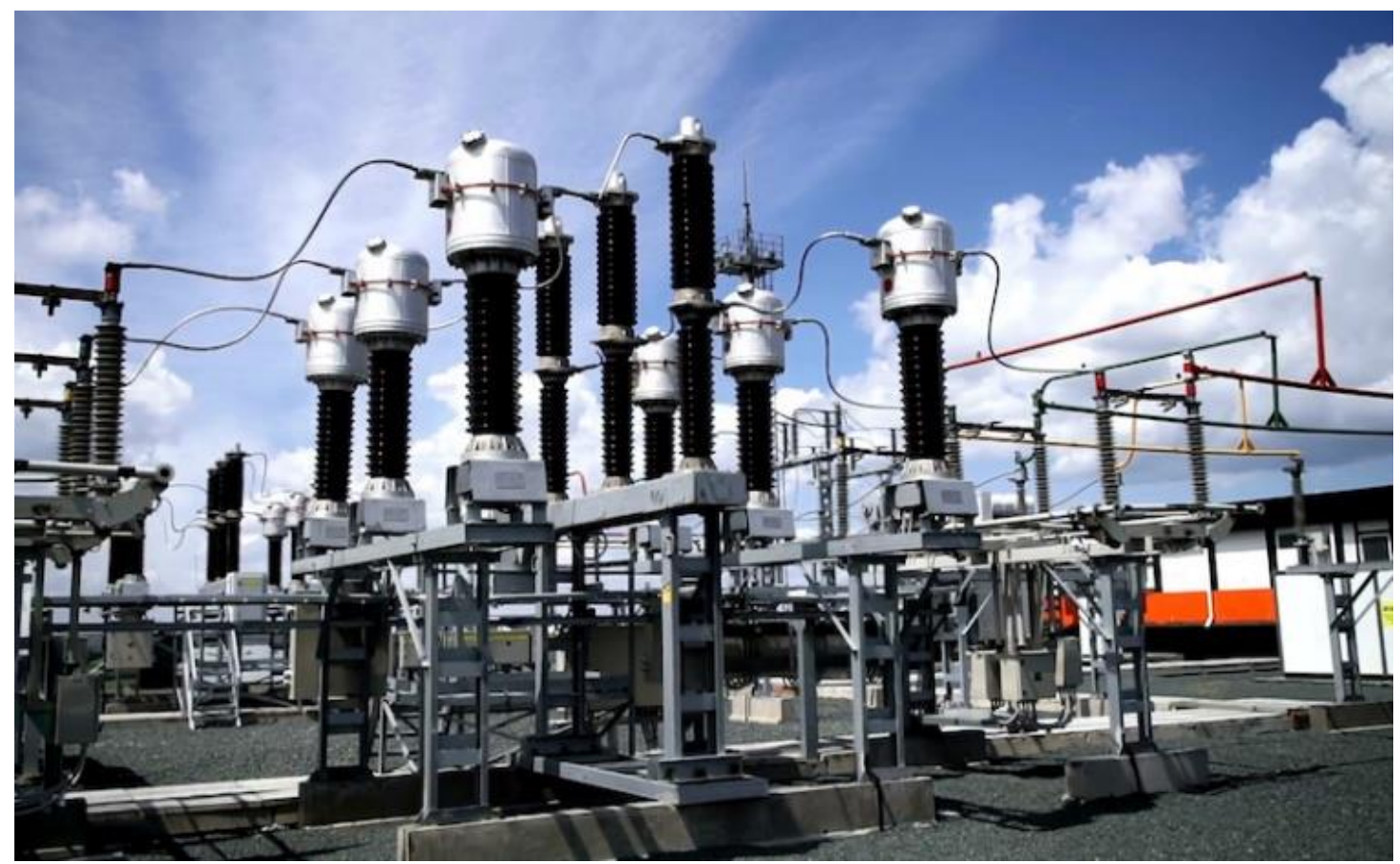

Figure 2. Nigeria's power grid project 


\subsection{Infrastructural challenges in Nigeria}

The following are the obstacles to infrastructural growth (development) in Nigeria:

\section{Corruption}

Corruption not only increases the cost of infrastructure; it also has the potential to decrease the value of earnings on infrastructural development. Nigeria's corruption level is exceptionally high and intolerable for good infrastructure. EFCC, ICPC, and the Bureau of Public Procurement (BPP) have all failed to remove corruption in the country. In 2010, the BPP saved the country a remarkable N216.6 billion by evaluating contract processes before the issue of Certificates of No Objection.

\section{Method of Acquisition}

Criticisms have been leveled at the procurement techniques used. The Public Finance Initiatives, particularly the Concession Method and Public or Private Partnership (PPP), are dubious and appear to mortgage the scheme's future to those not a part of it. The 105-kilometer Ibadan-Lagos Expressway, which the government gave to Bi-Courtney Consortium in 2009 for N89.53 billion over 25 years under the PPP program, is not the optimal configuration and has had little effect on the state of the roads.

\section{PESTLE}

PESTLE Analysis can be used to discuss the issues of infrastructure development in Nigeria. The difficulties associated with infrastructure development can be classified as political, economic, social, technological, legal, environmental, and safety. Political environment refers to the political stability, policymaking, and governance of the project's internal and external environments. The economic climate is concerned with interest rates, inflation, foreign exchange rates, and price volatility. The social context has an impact on worker diversity, which includes cultural and generational differences. The technological environment is concerned with the machines that are utilized to carry out undertakings. Physical environmental factors such as the terrain, geography, and climatology of the site are also critical. Safety concerns concern on-site assets' safety, security, and health, including human, material, and financial resources.

While other regions have addressed these issues through specific projects, Nigeria lacks a shared strategic vision for infrastructural development. Effective governance is critical to ensure the provision of infrastructure is both practical and efficient. This is mainly because a strong government ensures that resource allocations align with national goals to meet public demands.

\section{Supply and Demand}

Due to the failures of most leaders in terms of infrastructural provision, demand for infrastructural development has surpassed the requirement. Also, Nigeria has a surface mass of 9.1 million square kilometers and a population of over $180,000,000$, and a total road network of 193,200 kilometers, including 34,123 kilometers of federal highways and 30,500 kilometers of state 129,577 kilometers of local government highways. Regrettably, more than $70 \%$ of public roads are in poor condition. In addition, Nigeria needs approximately $17,000,000$ housing units and 60 trillionaires to address its housing demands.

\section{THE EFFECT ON THE NIGERIAN'S ECONOMY}

Like many other states in Sub-Saharan Africa, Nigeria has struggled to develop its economies due to inefficient infrastructure. This deplorable state of infrastructure has piqued the interest of some African countries, particularly in terms of attracting foreign investment, as infrastructure development is one of the critical factors of FDI entry into any economy. To achieve her vision of becoming one of the world's top 20 economies by 2030, Nigeria must prioritize infrastructure development. According to Remi Babalola and ex-state minister of finance, the country will require over $\$ 100$ billion to create a new infrastructure development framework within the next five years.

The majority of Nigeria's current infrastructure was created between 1970 and 1974 as part of the country's second national developmental plan. According to the Ref. [9], it is unsurprising that the second national plan places a premium on political change to establish the groundwork for the development of public infrastructure for productive and consuming reasons due to the country's oil boom. However, because of the high volatility of the oil market and the poor implementation of the national plan, the government began a series of economic reforms, which resulted in the neglect of the country's infrastructure and underinvestment. This negligence and lack of investment have had a significant impact on the economy, increasing the cost of various raw commodities and consequently reducing the country's productivity and competitiveness. This negligence also negatively impacts the state of the country's power supply, aviation networks, road networks, railway services, and abandoned construction projects in education, health, housing, and transportation. Furthermore, lack of investment in infrastructure has negatively impacted the influx of Capital (FDI) into the country. Most investors would always flock to countries with sufficient infrastructure Sadly, many enterprises have even relocated out of the country due to the lack of infrastructure.

\section{CONCLUSIONS AND RECOMMENDATIONS}

Infrastructure development in Nigeria has numerous obstacles. Demand exceeds supply, and the financing necessary to expedite collection is unavailable. Due to the widening gap between supply and demand, the government in all sectors is falling behind. Foreign investors are not encouraged by the political climate, and the Government does not prioritize infrastructural development.

Only sound governance will be able to close this gap. Furthermore, effective management fosters accountability, lowers corruption, and minimizes waste of resources due to efficiency. Finally, sound governance promotes economic and political stability. It mitigates the risk caused by massive, bumpy infrastructure expenditures, thereby enabling the mobilization of private and public sector funds for infrastructural development.

\section{REFERENCES}

[1] O'Sullivan, A, Sheffrin, M.S. (2003). Economics: Principles in Action. Upper Saddle River, New Jersey 07458: Pearson Prentice Hall. 
[2] Fulmer, J. (2009). What in the world is infrastructure? PEI Infrastructure Investor, pp. 30-32. Available: https://30kwe1si3or29z2y020bgbet-wpengine.netdnassl.com/wp-content/uploads/2018/03/what-in-theworld-is-infrastructure.pdf.

[3] Nair, P., Kumar, D. (2005). Mumbai urban transport project - Development and challenges. Urban/Regional 0505006, University Library of Munich, Germany, pp. 34-42.

[4] Festus, I.A., Amos, I.O. (2015). Housing policy in Nigeria: An overview. Am. Int. J. Contemp. Res., 5(2): 53-59. [Online]. Available: www.aijcrnet.com/journals/Vol_5_No_2_April_2015/8. pdf.

[5] Ajanlekoko, J.S. (2001). Sustainable housing development in Nigeria - The financial and infrastructural implication. Available at http://www.fig.net/pub/proceedings/nairobi/ajanlekokoc mws1-1.pdf, accessed on March 4, 2012.

[6] Nubi, T.O. (2000). Housing Finance in Nigeria: Need for
Re-engineering. Available at http://www.housingfinance.org/uploads/Publicationsma nager/Africa_EFFECTIVE\%20MOBILIZATION\%20H OUSING\%20-\%20Nigeria.pdf, accessed on March 4, 2012.

[7] Adeyinka, S.A., Omisore, E.O., Olawuni, P.O. (2006). An evaluation of informal sector activities and urban land use management in South Western Nigeria. Shap. Chang., 44(9): 8-13. [Online]. Available: http://www.fig.net/pub/fig2006/papers/ts35/ts35_02_ad eyinka_etal_0641.pdf.

[8] Oyedele, O.A. (2006). Effects of Waste dumps values of adjoining properties: A case study of Abule-Egba Waste Dump. Being Unpublished Thesis Submitted to the Senate of University of Ibadan, Nigeria, in partial fulfillment of the conditions for the award of Master of Science in Housing.

[9] Plan, N.D., Plans, D. (1970). Nigeria 's Second National Development. Afr. Aff. (Lond), 8(24): 146-158. 